\title{
PENGARUH KEPEMIMPINAN DAN PENILAIAN PRESTASI KERJA TERHADAP MOTIVASI KERJA KARYAWAN PADA KANTOR PDAM TIRTA TAMAN SARI KOTA MADIUN
}

\author{
Maya Hanjar Elifa Purnomo \\ Pendidikan Ekonomi FKIP UNIVERSITAS PGRI MADIUN \\ hanjarmaya@gmail.com
}

\begin{abstract}
The formulation of the problem in this research is whether there is an influence between leadership and performance appraisal of work motivation. The purpose of this study was to determine the influence between the influence between leadership and performance appraisal of work motivation where empirical study in this research is PDAM Tirta Taman Sari Madiun Office. This research uses quantitative method. collection techniques in this study with questionnaires and observations. The method of analysis used is descriptive method by using multiple linear regression for hypothesis testing. The result of hypothesis testing shows that leadership and job performance appraisal have an effect on employee work motivation at PDAM Tirta Taman Sari Office of Madiun City. The value of Fcount is 21,371, while Ftable is 3.06, Sighitung is 0,000 while Sigprob is 0.05. This means that the value of Fcount $\geq$ Ftable $(21,371 \geq 3.06)$ or Sighitung $\leq$ Sigtabel $(0.000 \leq 0,05)$, or it can be concluded reject $\mathrm{HO}$, meaning there is total influence between leadership and job performance appraisal to work motivation at PDAM Tirta Office Taman Sari Madiun City.
\end{abstract}

Keywords: Leadership, Performance Appraisal, Employee Motivation.

\begin{abstract}
Abstrak
Rumusan masalah dalam penelitian ini adalah apakah terdapat pengaruh antara kepemimpinan dan penilaian prestasi kerja terhadap motivasi kerja. Tujuan penelitian ini adalah untuk mengetahui adanya pengaruh antara pengaruh antara kepemimpinan dan penilaian prestasi kerja terhadap motivasi kerja dimana studi empiris dalam penelitian ini adalah Kantor PDAM Tirta Taman Sari Kota Madiun. Penelitian ini menggunakan metode kuantitatif. Teknik pengumpulan data dalam penelitian ini dengan kuesioner dan observasi . Metode analisis yang digunakan adalah metode deskripstif dengan menggunakan regresi linier berganda untuk pengujian hipotesis. Hasil pengujian hipotesis menunjukkan bahwa kepemimpinan dan penilaian prestasi kerja berpengaruh terhadap motivasi kerja karyawan pada Kantor PDAM Tirta Taman Sari Kota Madiun. Nilai Fhitung adalah 21,371, sedangkan $\mathrm{F}_{\text {tabel }}$ sebesar 3,06, $\mathrm{Sig}_{\text {hitumg }}$ adalah 0,000 sedangkan $\operatorname{Sig}_{\text {prob }} 0,05$. Hal ini berarti nilai $\mathrm{F}_{\text {hitung }} \geq \mathrm{F}_{\text {tabel }}$ $(21,371 \geq 3,06)$ atau $\operatorname{Sig}_{\text {hitung }} \leq \operatorname{Sig}_{\text {tabel }}(0,000 \leq 0,05)$, atau dapat disimpulkan tolak $\mathrm{H}_{0}$, artinya ada pengaruh secara keseluruhan antara kepemimpinan dan penilaian prestasi kerja terhadap motivasi kerja pada Kantor PDAM Tirta Taman Sari Kota Madiun.
\end{abstract}

Kata Kunci: Kepemimpinan, Penilaian Prestasi Kerja, Motivasi Kerja Karyawan 


\section{PENDAHULUAN}

Sumber daya manusia merupakan faktor yang paling penting terutama bagi suatu organisasi atau suatu perusahaan, baik yang bergerak dalam bidang produksi maupun dalam bidang pelayanan jasa .

Menurut Umar (dalam Sunyoto, 2013: 1) manajemen sumber daya manusia adalah suatu perencanaan, pengorganisasian, mengembangkan, memotivasi, dan memelihara kinerja yang tinggi dalam organisasi untuk mencapai tujuan organisasi.

Adanya motivasi dari diri karyawan, maka dapat meningkatkan semangat kerja yang tinggi. Namun apabila tidak ada motivasi dari diri karyawan, belum tentu pekerjaan dapat berjalan dengan baik dan hasil yang memuaskan. Pada setiap karyawan memiliki motivasi kerja yang berbeda.

Menurut Rivai (2004 : 455) “motivasi adalah serangkaian sikap dan nilai-nilai yang mempengaruhi individu untuk mencapai hal yang spesifik sesuai dengan tujuan individu".

Faktor yang dapat mempengaruhi motivasi kerja menurut Yunus (dalam Torang, 2014 : 59) yaitu faktor pemimpin. Kepemimpinan merupakan suatu ilmu yang mengkaji secara komprehensif tentang bagaimana mengarahkan, mempengaruhi, dan mengawasi orang lain untuk mengerjakan tugas sesuai dengan perintah yang direncanakan.

Menurut Tangkilisin (2007:7) mengatakan "pemimpin adalah orang yang memiliki satu atau beberapa kelebihan sebagai bakat yang dibawa sejak lahir dan merupakan kebutuhan dari suatu situasi atau zaman, sehingga orang itu mempunyai kekuatan dan kewibawaan untuk mengarahkan dan membimbing bawahannya".

Selain dari faktor kepemimpinan, menurut Burhanuddin (2015:204) dengan penilaian prestasi kerja yang dilaksanakan dengan baik dan tertib, maka akan dapat membantu dalam meningkatkan motivasi kerja dan loyalitas organisasional karyawan.
Menurut Subekhi dan Jauhar (2012 : 172) "penilaian prestasi kerja adalah suatu proses yang bertujuan untuk mengetahui atau memahami tingkat kinerja karyawan dibandingkan dengan tingkat kinerja karyawan lainnya atau dibandingkan dengan standar yang telah ditetapkan". Kepemimpinan dan penilaian prestasi kerja merupakan faktor yang dapat meningkatkan motivasi kerja.

Kantor Perusahaan Daerah Air Minum (PDAM) adalah perusahaan yang bergerak di bidang pelayan air bersih. PDAM melayani masyarakat untuk memperoleh air bersih agar masyarakat dapat hidup sehat dengan adanya air bersih. PDAM juga melayani masyarakat dengan penuh tanggung jawab dan sikap ramah terhadap semua masyarakat yang datang pada Kantor PDAM Tirta Taman Sari Kota Madiun.

\section{METODE PENELITIAN}

Penelitian dilaksanakan di Kantor PDAM Tirta Taman Sari Kota Madiun, J1. Sulawesi No. 18, Kartoharjo, Kabupaten Madiun. Alasan pemilihan tempat tersebut dikarenakan letak objek penelitian tidak terlalu jauh sehingga diperoleh dan pelayanannya sangat baik. Desain penelitian yang digunakan dalam penelitian ini menggunakan hubungan sebab akibat (kausal). "Penelitian kuantitatif dalam melihat hubungan variabel terhadap objek yang diteliti lebih bersifat sebab akibat (kausal), sehingga dalam penelitian ada variabel independen dan dependen.

Populasi dalam penelitian ini adalah seluruh karyawan yang ada pada Kantor PDAM Tirta Taman Sari Kota Madiun sebanyak 144 karyawan sekaligus digunakan untuk sampel. Pengambilan sampel dilakukan dengan teknik Sampling Jenuh. Teknik pengumpulan data yang digunakan adalah:

1. Kuesioner

Metode pengumpulan data dengan menggunakan teknik angket dengan menggunakan skala likert. Jumlah soal 
yang dibagi dalam 2 variabel, dengan perincian untuk variabel kepemimpinan 10 soal, penilaian prestasi kerja 8 soal, dan Variabel motivasi kerja 16 soal.

2. Observasi

Dalam penelitian ini metode observasi dilakukan dengan cara peninjauan secara langsung ke objek penelitian yaitu Kantor PDAM Tirta Taman Sari Kota Madiun untuk memperoleh data yang diperlukan guna kelancaran penyusunan penelitian yang berkaitan dengan judul yang diteliti.

1. Uji Prasarat atau Instrumen

a. Uji Validitas

Dalam uji validitas digunakan korelasi productmoment.

b. Uji Reliabilitas

Uji Reliabilitas pada penelitian ini dilakukan dengan menggunakan rumus alpha cronbach. Menurut Noor (2011:165)

2. UjiAsumsi Klasik

Uji Asumsi Klasik dalam penelitian ini menggunakan Uji Normalitas, Uji Heteroskedastisitas, Uji Multikolerasi, UjiAutokorelasi.

a. Uji Normalitas

Uji normalitas bertujuan untuk menguji apakah dalam model regresi variabel pengganggu atau residual memiliki distribusi normal (Ghozali, 2011:160). Pengujian menggunakan uji Kolmogorov-Smirnov (Analisis Explore).

b. Uji Heteroskesdastisitas

Uji heteroskedastisitas bertujuan menguji apakah dalam model regresi terjadi ketidaksamaan varian dari residual satu pengamatan ke pengamatan lain (Ghozali, 2013:139). Pada uji heteroskesdastisitas grafik menggunakan scatterplot dan menggunakan uji glejser.

c. Uji Multikolonieritas

Multikolonieritas dapat disebab- kan karena adanya efek kombinasi dua atau lebih variabel independen (Ghozali, 2013:105). Untuk mendeteksi ada atau tidaknya multikolonieritas di dalam model regresi dilihat dari nilai tolerance dan variance inflation factor (VIF).

d. Uji Autokorelasi

Uji autokolerasi bertujuan menguji apakah model regresi linier ada korelasi antara kesalahan pengganggu pada periode t-1 sebelumnya (Ghozali, 2011: 110). Uji Autokorelasi menggunakan yaitu dengan melakukan uji statistik Durbin-Watson.

3. Uji Hipotesis atau Analisis Data

Untuk uji hipotesis menggunakan teknik analisis regresi linier berganda menggunakan koefisien determinasi dan uji t. Koefisien determinasi digunakan untuk menguji pengaruh antara variabel satu dengan yang lain. Variabel yang dimaksud adalah variabel independen yaitu Kepemimpinan dan Penilaian Prestasi Kerja dan variabel dependen yaitu Motivasi Kerja (Y). Sedangkan uji t untuk mengetahui apakah variabel bebas secara individu mempunyai pengaruh yang signifikan terhadap variabel terikat.

\section{HASIL DAN PEMBAHASAN}

a. Dideskripsikan bahwa Kepemimpinan dengan jumlah data $(\mathrm{N})$ sebanyak 144 responden mempunyai deskripsi data sebagai berikut: (a) Jumlah skor total sebesar 6331; (b) Nilai rata-rata hitung (mean) sebesar 43,96; (c) Median sebesar 46,00; (d) Modus sebesar 47; (e) Standar deviasi sebesar 4,628; (f) Nilai minimum sebesar 32; (g) Nilai maximum sebesar 50. Berdasarkan nilai di atas yang mendapatkan nilai di atas rata-rata sebanyak 94 atau $65 \%$, sedangkan yang mendapat nilai di bawah rata-rata sebanyak 50 atau $35 \%$, artinya bahwa kepemimpinan sudah cukup baik. 
b. Dideskripsikan bahwa Penialian Prestasi Kerja dengan jumlah data (N) sebanyak 144 responden mempunyai deskripsi data sebagai berikut: (a) Jumlah skor total sebesar 5191; (b) Nilai rata-rata hitung (mean) sebesar 36,04; (c) Median sebesar 37,00; (d) Modus sebesar 37; (e) Standar deviasi sebesar 3,004; (f) Nilai minimum sebesar 27; (g) Nilai maximum sebesar 40. Berdasarkan nilai di atas yang mendapatkan nilai di atas rata-rata sebanyak 96 atau $66 \%$, sedangkan yang mendapat nilai di bawah rata-rata sebanyak 49 atau 34\%, artinya bahwa Penilaian Prestasi Kerja sudah cukup baik.

c. Dideskripsikan bahwa Motivasi Kerja dengan jumlah data $(\mathrm{N})$ sebanyak 144 responden mempunyai deskripsi data sebagai berikut: (a) Jumlah skor total sebesar 9904; (b) Nilai rata-rata hitung (mean) sebesar 68,77; (c) Median sebesar 70,00; (d) Modus sebesar 72; (e) Standar deviasi sebesar 5,378; (f) Nilai minimum sebesar 52; (g) Nilai maximum sebesar 77. Berdasarkan nilai di atas yang mendapatkan nilai di atas rata-rata sebanyak 102 atau $71 \%$, sedangkan yang mendapat nilai di bawah rata-rata sebanyak 42 atau 29\%, artinya bahwa Motivasi Kerja sudah cukup baik.

\section{Hasil Uji Validitas}

Hasil dari uji validitas angket Kepemimpinan diuji kepada karyawan di Kantor PDAM Tirta Taman Sari Kota Madiun berjumlah 144 responden. Dari 10 soal Kepemimpinan yang diuji hasilnya semua valid. Hasil dari uji validitas angket Penilaian Prestasi Kerja di uji kepada karyawan di Kantor PDAM Tirta Taman Sari Kota Madiun berjumlah 144 responden. Dari 8 soal Penilaian Prestasi Kerja yang diuji hasilnya semua valid dan dapat dipergunakan oleh peneliti sebagai instrumen penelitian.

\section{Hasil Uji Reliabilitas}

Uji Reliabilitas pada penelitian ini dilakukan dengan menggunakan rumus alpha cronbach. Menurut Noor (2011:165) kriteria suatu instrument penelitian dapat diketahui sebagai berikut :

Untuk menentukan reliabilitas dapat dilihat dari nilai Alfa jika alfa lebih besar dari nilai rtabel, maka dapat dikatakan reliabel jika nilai $r>0,60$.

Hasil uji reliabilitas variabel Kepemimpinan, Penilaian Prestasi Kerja dan Motivasi Kerja dan adalah 0,830, 0,706 dan 0,813 maka semua dinyatakan reliabel.

\section{Hasil Uji Asumsi Klasik}

a. Uji Normalitas

Hasil uji normalitas dengan menggunakan uji Kolmogorov-Smirnov (Analisis Explore) yang terdapat di atas bahwa nilai Assymp Sig sebesar 0,248 lebih besar dari 0.05 , dengan demikian dapat disimpulkan bahwa data yang akan dianalisis terdistribusi normal.

b. Uji Heteroskesdastisitas

Berdasarkan hasil output hasil uji Glejser terlihat Kepemimpinan (X1) memiliki nilai signifikan 0,079 dan Penilaian Prestasi Kerja (X2) memiliki nilai signifikan 0,316, hal tersebut terlihat dari probabilitas signifikansinya di atas kepercayaan 0,05 sehingga dapat disimpulkan bahwa tidak ada indikasi Heteroskedastisitas.

c. Uji Multikolonieritas

Hasil penelitian dapat diketahui bahwa dalam uji multikoloinieritas terdapat nilai tolerance pada variabel kepemimpinan $\left(\mathrm{X}_{1}\right)$ sebesar $0,773>0,10$ dan nilai tolerance penilaian prestasi kerja $\left(\mathrm{X}_{2}\right)$ $0,773>0,10$ dan nilai VIF variabel kepemimpinan $\left(\mathrm{X}_{1}\right)$ sebesar 1,294<10,00 dan nilai VIF variabel penilaian prestasi kerja $\left(\mathrm{X}_{2}\right)$ sebesar 1,294 < 10,00 maka dapat disimpulkan data tidak terjadi multikolonieritas. 


\section{d. Uji Autokorelasi}

Dapat diketahui nilai batas atas (du) sebesar 1,755, nilai Dw sebesar 2,111, dan nilai 4-1,755 (4-du) sebesar 2,225. Uji autokorelasi di atas menunjukkan bahwa nilai $\mathrm{du} \leq \mathrm{dw} \leq 4$-du $(1,755 \leq 2,111 \leq$ $2,225)$, artinya tidak ada autokorelasi pada model regresi yang diteliti.

\section{Uji Regresi Linier Berganda}

Uji Regresi Linier sederhana diperoleh persamaan $\mathrm{Y}=36,163+0,311 \mathrm{X} 1+0,525 \mathrm{X} 2$. Konstanta sama dengan 36,163 artinya apabila variabel Motivasi dan Disiplin kerja bernilai tetap atau konstant, maka besarnya Kinerja Karyawan adalah 36,163.

\section{Koefisien Determinasi $\left(\mathbf{R}^{2}\right)$}

Dari hasil pengolahan data dengan menggunakan program SPSS versi 16.0 dapat diketahui bahwa koefisien determinasi $\left(\mathrm{R}^{2}\right)$ yang diperoleh sebesar 0,222. Yang artinya, Kepemimpinan dan Penilaian Prestasi Kerja berpengaruh terhadap Motivasi Kerja pada Kantor PDAM Tirta Taman Sari Kota 22,2\% sedangkan sisanya sebesar $77,8 \%$ dipengaruhi oleh faktor lain yang tidak diteliti.

\section{Uji T}

Dari hasil perhitungan uji $\mathrm{t}$ diperoleh nilai sebagai berikut :

a. Berdasarkan hasil penelitian maka dapat diketahui bahwa $\mathrm{t}_{\text {hitung }}$ variabel $\mathrm{X}_{1}$ sebesar 3,193 dengan $t_{\text {tabel }} 1,976$. Nilai ini lebih besar dari $\mathrm{t}_{\text {tabel }}(3,193>1,976)$ dan nilai sig $0,002 \leq 0,05$. Hal ini menunjukkan bahwa secara parsial variabel kepemimpinan mempunyai pengaruh positif terhadap variabel motivasi kerja.

b. Sedangkan untuk variabel $\mathrm{X}_{2}$ maka dapat diketahui bahwa $\mathrm{t}_{\text {hitung }}$ variabel $\mathrm{X}_{2}$ sebesar 3,495 dengan $t_{\text {tabel }} 1,976$. Nilai ini lebih besar dari $\mathrm{t}_{\text {tabel }}(3,496>1,976)$ dan nilai sig $0,001 \leq 0,05$. Hal ini menunjukkan bahwa secara parsial variabel penilaian prestasi kerja mempunyai pengaruh positif terhadap variabel motivasi kerja.

\section{Uji F}

Dari hasil perhitungan uji $\mathrm{t}$ diperoleh nilai sebagai berikut :

Hasil F tabel diperoleh sebesar 3,06. Pada tabel di atas dapat diperoleh nilai $\mathrm{F}$ hitung sebesar 21,737 dan Sig. sebesar 0,000, sehingga $21,371 \geq 3,06$ dan $0,000 \leq 0,05$, maka dari itu membuktikan hipotesis ketiga menyatakan bahwa berarti variabel Kepemimpinan dan Penilaian Prestasi Kerja secara bersama-sama berpengruh secara signifikan terhadap variabel Motivasi Kerja Karyawan Kantor PDAM Tirta Taman Sari Kota Madiun.

\section{PEMBAHASAN}

a. Kepemimpinan Terhadap Motivasi Kerja Hasil penelitian menunjukkan bahwa kepemimpinan berpengaruh terhadap motivasi kerja pada Kantor PDAM Tirta Taman Sari Kota Madiun. Hal ini diperkuat oleh penelitian terdahulu dari Hasmi, Gunawan, Andi (2016) bahwa dalam penelitiannya kepemimpinan berpengaruh secara simultan terhadap motivasi kerja. Berdasarkan penelitian ini dapat diketahui bahwa kepemimpinan memiliki pengaruh terhadap motivasi kerja karyawan pada Kantor PDAM Tirta Taman Sari Kota Madiun.

b. Penilaian Prestasi Kerja Terhadap Motivasi Kerja

Hasil penelitian menunjukkan bahwa penilaian prestasi kerja berpengaruh terhadap motivasi kerja pada Kantor PDAM Tirta Taman Sari Kota Madiun. Penelitian ini didukung dengan adanya penelitian yang telah dilakukan oleh Sarboini, Adam, dan Mardani (2015) yang melakukan penelitian dan memperoleh hasil bahwa penilaian prestasi kerja yang dilakukan oleh perusahaan maka 
akan membantu dan mempermudah bagian manajemen dalam pengambilan keputusan serta membuat motivasi karyawan meningkat. Berdasarkan penelitian ini dapat diketahui bahwa penilaian prestasi kerja memiliki pengaruh terhadap motivasi kerja karyawan pada Kantor PDAM Tirta Taman Sari Kota Madiun.

c. Kepemimpinan dan Penilaian Prestasi Kerja Terhadap Motivasi Kerja

Hasil penelitian menunjukkan bahwa kepemimpinan dan penilaian prestasi kerja berpengaruh terhadap motivasi kerja pada Kantor PDAM Tirta Taman Sari Kota Madiun.

Penelitian ini didukung dengan adanya penelitian yang telah dilakukan oleh Reni (2015) yang telah melakukan penelitian dan memperoleh hasil bahwa kepemimpinan berpengaruh terhadap motivasi kerja, sedangkan Sarboini, Adam, dan Mardani (2015) melakukan penelitian dan memperoleh hasil bahwa penilaian prestasi kerja yang dilakukan oleh perusahaan maka akan dapat meningkatkan motivasi kerja. Berdasarkan penelitian ini dapat diketahui bahwa kepemimpinan dan penilaian prestasi kerja secara simultan berpengaruh terhadap Motivasi kerja karyawan Pada Kantor PDAM Tirta Taman Sari Kota Madiun.

\section{PENUTUP}

\section{Simpulan}

Berdasarkan hasil analisis data dan pembahasan yang telah dilakukan pada bab sebelumnya, maka dapat disimpulkan sebagai berikut:

1. Kepemimpinan pada Kantor PDAM Tirta Taman Sari Kota Madiun sudah cukup baik. Hal ini dibuktikan dari 144 karyawan memiliki nilai di atas rata-rata sebanyak 94 atau $65 \%$, sedangkan yang di bawah rata-rata sebesar 50 atau $35 \%$.
2. Penilaian Prestasi Kerja pada Kantor PDAM Tirta Taman Sari Kota Madiun sudah cukup baik. Hal ini dibuktikan dari 144 karyawan memiliki nilai di atas ratarata sebanyak 96 atau 66\%, sedangkan yang di bawah rata-rata sebesar 48 atau $33 \%$.

3. Motivasi Kerja pada Kantor PDAM Tirta Taman Sari Kota Madiun sudah cukup baik. Hal ini dibuktikan dari 144 karyawan memiliki nilai di atas rata-rata sebanyak 102 atau 71\%, sedangkan yang di bawah rata-rata sebesar 42 atau $29 \%$.

4. Kepemimpinan (X1) berpengaruh positif terhadap Motivasi Kerja pada karyawan Kantor PDAM Tirta Taman Sari Kota Madiun dengan hasil penelitian menunjukkan bahwa $t_{\text {hitung }}$ variabel $X_{1}$ sebesar 3,193 dengan $t_{\text {tabel }}$ 1,976. Nilai ini lebih besar dari $\mathrm{t}_{\text {tabel }}(3,193>1,976)$ dan nilai sig $0,002 \leq 0,05$.

5. Penilaian Prestasi Kerja (X2) berpengaruh positif terhadap Motivasi Kerja pada Kantor PDAM Tirta Taman Sari Kota Madiun dengan hasil penelitian menunjukkan bahwa $t_{\text {hitung }}$ variabel $\mathrm{X}_{2}$ sebesar 3,495 dengan $t_{\text {tabel }} 1,976$. Nilai ini lebih besar dari $\mathrm{t}_{\text {tabel }}(3,495>1,976)$ dan nilai sig $0,001 \leq 0,05$.

6. Kepemimpinan (X1) dan penilaian prestasi kerja (X2) secara simultan berpengaruh terhadap motivasi kerja $(\mathrm{Y})$ dengan hasil $\mathrm{F}$ tabel diperoleh sebesar 3,06. Pada tabel di atas dapat diperoleh nilai $F$ hitung sebesar 21,371 dan Sig. sebesar 0,000 , sehingga $21,371 \geq 3,06$ dan $0,000 \leq 0,05$.

\section{Saran}

1. Kantor PDAM Tirta Taman Sari Kota Madiun

a. Perlu adanya peningkatkan motivasi kerja karyawan baik motivasi yang bersifat finansial (dorongan yang dilakukan dengan memberikan 
imbalan finansial kepada karyawan, imbalan finansial tersebut sering disebut intensif) maupun non finansial (dorongan yang diwujudkan tidak dalam bentuk finansial atau uang, akan tetapi berupa hal-hal seperti pujian, penghargaan, dan pendekatan manusiawi). Selain itu dengan menjalin komunikasi yang baik dengan cara memberikan arahan dan dorongan kepada karyawannya agar meningkatkan motivasi kerja.

b. Kepemimpinan harus memberikan contoh kepada karyawannya dengan cara selalu mematuhi peraturan agar para karyawan dapat termotivasi dan memberikan sanksi yang benar-benar agar karyawan bisa lebih disiplin.

c. Pemimpin juga perlu memperhatikan apa yang yang dibutuhkan oleh karyawan dalam melakukan pekerjaan.

\section{Bagi Karyawan}

a. Karyawan harus selalu semangat bekerja karena motivasi yang diberikan pemimpin perusahaan sudah sesuai dan baik. Pemimpin harus sering memberikan dorongan dan sering berkomunikasi dengan karyawan agar karyawan dapat meningkatkan motivasi kerja.

b. Karyawan harus mematuhi dan selalu mengikuti penilaian prestasi kerja yang dilakukan oleh perusahaan agar dapat mengetahui sampai mana prestasi kerja karyawan serta untuk meningkatkan motivasi kerja.
3. Peneliti Selanjutnya

Bagi peneliti selanjutnya diharapkan untuk meneruskan penelitian ini dengan menggunakan variabel lain di luar penelitian ini, mengingat masih ada banyak kemungkinan besar variabel lain yang dapat berpengaruh terhadap motivasi kerja, sehingga dapat memperluas pengetahuan dan menambah hasil penelitian.

\section{DAFTAR PUSTAKA}

Burhanuddin Yusuf. 2015. Manajemen Sumber Daya Manusia di Lembaga Keuangan Syariah. Jakarta. PT. Raja Grafindo Persada.

Akhmad Subekti \& Jauhar. M. 2012. Pengantar Manajemen Sumber Daya Manusia (MSDM). Jakarta : Prestasi Pustakarya.

Ghozali. 2013. Aplikasi Analisis Multivariate dengan Program SPPS 18. Semarang: Badan Penerbit Universitas Diponegoro.

Noor, Juliansyah. 2011. Metodologi Penelitian : Skripsi, Tesis, Disertasi, dan Karya Ilmiah. Jakarta: Kencana.

Sugiyono. 2010. Metode Penelitian Pendidikan (Pendekatan Kuantitatif Kualitatif dan $R$ \& D). Bandung : Alfabeta.

Sunyoto, Danang. 2013. Teori, Kuesioner dan Analisis Data Sumber Daya Manusia. Yogyakarta. CAPS (Center for Academic Publishing Service).

Torang, Syamsir. 2014. Organisasi dan Manajemen. Bandung: Alfabeta. 